\title{
Benefits of Low Electron-Affinity Material as the N-Type Layer for $\mathrm{Cu}(\mathrm{In}, \mathrm{Ga}) \mathrm{S}_{2}$ Solar Cell
}

\author{
Dwinanri Egyna *(D), Kazuyoshi Nakada (D) and Akira Yamada (D)
}

Department of Electrical and Electronic Engineering, Tokyo Institute of Technology, Ookayama, Meguro-ku, Tokyo 152-8552, Japan; knakada@tcu.ac.jp (K.N.); yamada.a.ac@m.titech.ac.jp (A.Y.)

* Correspondence: egyna.d.aa@m.titech.ac.jp; Tel.: +81-80-8862-8471

Citation: Egyna, D.; Nakada, K.;

Yamada, A. Benefits of Low

Electron-Affinity Material as the N-Type Layer for $\mathrm{Cu}(\mathrm{In}, \mathrm{Ga}) \mathrm{S}_{2}$ Solar Cell. Energies 2022, 15, 4. https:// doi.org/10.3390/en15010004

Academic Editor: Laurentiu Fara

Received: 1 November 2021 Accepted: 8 December 2021 Published: 21 December 2021

Publisher's Note: MDPI stays neutral with regard to jurisdictional claims in published maps and institutional affiliations.

Copyright: (c) 2021 by the authors. Licensee MDPI, Basel, Switzerland. This article is an open access article distributed under the terms and conditions of the Creative Commons Attribution (CC BY) license (https:/ / creativecommons.org/licenses/by/ $4.0 /)$.

\begin{abstract}
Despite the potential in single- and multi-junction solar cells application, research into the wide band gap $\mathrm{CuIn}_{1-x} \mathrm{Ga}_{x}\left(\mathrm{Se}_{1-y} \mathrm{~S}_{y}\right)_{2}$ or $\mathrm{CIG}(\mathrm{SSe})_{2}$ solar cell material, with $E_{g} \geq 1.5 \mathrm{eV}$, has yet to be extensively performed to date. In this work, we conducted a numerical study into the role of the ntype layers in $\mathrm{CIG}(\mathrm{SSe})_{2}$ heterojunction solar cells, specifically concerning the maximum open-circuit voltage of the devices. In the first part of the study, we derived a new ideal open-circuit voltage equation for a thin-film heterojunction solar cell by taking into account the current contribution from the depletion region. The accuracy of the new equation was validated through a simulation model in the second part of the study. Another simulation model was also used to clarify the design rules of the n-type layer in a wide band gap $\mathrm{CIG}(\mathrm{SSe})_{2}$ solar cell. Our work stressed the importance of a positive conduction band offset on the n-/p-type interface, through the use of a low electron affinity n-type material for a solar cell with a high open-circuit voltage. Through a precise selection of the window layer material, a buffer-free $\mathrm{CIG}(\mathrm{SSe})_{2}$ design is sufficient to fulfill such conditions. We also proposed the specific roles of the n-type layer, i.e., as a passivation layer and selective electron contact, in the operation of $\mathrm{CIGS}_{2}$ solar cells.
\end{abstract}

Keywords: $\mathrm{CIGS}_{2}$ solar cells; thin-film heterojunction; open-circuit voltage; n-type layer; $\mathrm{CuInGaS}_{2}$

\section{Introduction}

Chalcopyrite $\mathrm{CuIn}_{1-x} \mathrm{Ga}_{x}\left(\mathrm{Se}_{1-y} \mathrm{~S}_{y}\right)_{2}$ or $\mathrm{CIG}(\mathrm{SSe})_{2}$ solar cells are one of the prominent materials used in the thin-film solar cell technology. Unlike the first-generation solar cells, which are usually formed by a homogeneous pn-junction coupling, such as n-Si/p-Si, a mix of different materials is used to form a heterojunction coupling in thin-film solar cells. The absorber material of thin-film solar cells, such as CIG(SSe) $)_{2}$, has high absorption coefficient, which $\alpha$ [1,2] allows a comparable photon absorption to the thicker homojunction solar cells, even with less material use. The thin-film technology also enables for a wider field of application, one being to reduce the material cost in tandem solar cells. As an example, since spectral matching between the top and bottom cells is one of the challenges in the tandem solar cell technology, the band gap tunability of $\mathrm{CIG}(\mathrm{SSe})_{2}$ material, through the $\mathrm{Ga} / \mathrm{In}$ and the S/Se adjustment, serves as an extra advantage over other materials in the tandem solar cell applications. According to Coutts et al. in [3] and Meillaud et al. in [4], an optimum tandem solar cell requires a narrow-band gap materials with $E_{g}=1.1 \mathrm{eV}$ for the bottom cell and a wide band gap material, with $E_{g}=1.7 \mathrm{eV}$ for the top cell. The band gap of the CIGSe 2 material group can be adjusted between 1.0-1.7 eV, whereas the band gap of the $\mathrm{CIGS}_{2}$ material group can be modified between 1.5-2.4 eV [5,6]. A variation of $\mathrm{CIGSe}_{2}$ materials with the band gap in the narrower range is suitable for the bottom cell application [7], while the wider band gap CIGS $_{2}$ materials are suitable for the top cell application [8]. In addition to that, the band gap of low-Ga CIGS 2 is also very close to the ideal single-junction solar cell band gap for the best spectral matching application $[9,10]$.

Compared to its narrow-band gap counterpart, research into the wide band gap $\mathrm{CIG}(\mathrm{SSe})_{2}$ has yet to achieve favourable outcomes. As an example, band gap grading 
design, through Ga-content control, have had a significant impact [11,12], and numerous theoretical studies in band grading designs are still underway [13-15]. The additional step of absorber layer's post-deposition treatment (PDT) using alkali $[16,17]$ have also been known to have a positive impact on the CIGSe 2 solar cell's performance. In addition, the importance of the pn-junction interface between the buffer layer and the absorber layer in non-radiative recombination was identified empirically [18-20] and further validated through a numerical study [21]. The abundance of work on the narrow band gap $\mathrm{CIGSe}_{2}$ solar cells established the current efficiency record of $23.35 \%$ [22] for a single-junction narrow-band gap CIG(SSe) $)_{2}$ solar cell with $E_{g}=1.09 \mathrm{eV}$. In contrast, the current efficiency record for the wide band gap $\mathrm{CIGS}_{2}$ solar cell is $16.9 \%$ [23].

Several challenges in reaching high-efficiency wide band gap CIG(SSe) ${ }_{2}$ solar cells have been discussed in the past. In [24], Gloeckler and Sites suggested that interfacial recombination limited the open-circuit voltage of wide band gap pure-selenide $\mathrm{CIGSe}_{2}$ solar cells. The authors deduced that the standard $\mathrm{ZnO} / \mathrm{CdS}$ n-type layers coupling resulted in an inadequate conduction band alignment on a wide band gap CIGSe ${ }_{2}$ absorber. Wei and Zunger proposed an alternative window material, such as $\mathrm{Zn}(\mathrm{O}, \mathrm{S})$, in [25], in which the addition of $\mathrm{S}$ would adjust the conduction band minimum of $\mathrm{ZnO}$ to a better matching. Another alternative n-type layer was suggested by Larson et al. in [26]. In that experiment, $\mathrm{Zn}_{1-x} \mathrm{Sn}_{x} \mathrm{O}_{y}$ was used as the alternative n-type buffer layer. In the work, the authors claimed that the alternative material resulted in the highest known open-circuit voltage ever achieved empirically on a chalcopyrite solar cell at $V_{\mathrm{OC}}=1.017 \mathrm{~V}$.

Gloeckler and Sites also presented, in their paper, that the wide band gap material achieved by valence band control through $S$ addition resulted in a higher open-circuit voltage, compared to their similar band gap counterparts achieved through $\mathrm{Ga}$ addition [24]. An alternative, $\mathrm{Zn}_{1-x} \mathrm{Mg}_{x} \mathrm{O}_{y}$, was used as the alternative buffer layer material by Hiroi et al. [27], which improved the short-circuit current of the device, compared to that using the CdS buffer layer. Another improvement on $V_{\mathrm{OC}}$ was also observed in the study following the adjustment of the $\mathrm{Mg}$ concentration, from $\mathrm{Mg} /(\mathrm{Mg}+\mathrm{Zn})=0.193$ to $\mathrm{Mg} /(\mathrm{Mg}+\mathrm{Zn})=0.242$. The observed improvement agreed with a previous study by Minemoto et al., in [28], where the authors found that a change in $\mathrm{Mg} /(\mathrm{Mg}+\mathrm{Zn})$, from $x=0$ to $x=0.46$, resulted in the widening of $\mathrm{Zn}_{1-x} \mathrm{Mg}_{x} \mathrm{O}_{y}$ band gap, from $E_{g}=3.24 \mathrm{eV}$ to $E_{g}=4.20 \mathrm{eV}$, presumably resulting in a better conduction band matching on the buffer/absorber interface [29].

In addition to the performance improvement of $\mathrm{CIG}(\mathrm{SSe})_{2}$ solar cells fabricated from the wide band gap CIG(SSe $)_{2}$ absorber, the role of the n-type layer materials was also crucial in the development of buffer-free $\mathrm{CIG}(\mathrm{SSe})_{2}$ solar cells. The presence of n-type buffer layer was long deemed to be necessary in the conventional CIG(SSe $)_{2}$ solar cell's device structure to achieve high efficiency [30,31]. However, from the manufacturing perspective, the elimination of the buffer layer is preferable, in order to simplify the fabrication process and produce low-cost solar cell devices. Several studies on buffer-free $\mathrm{CIG}(\mathrm{SSe})_{2}$ structure have been done in the past. The application of alternative n-type materials, such as $\mathrm{ZnO}_{1-x} \mathrm{~S}_{x}: \mathrm{Al}$ [32] or $\mathrm{Zn}_{1-x} \mathrm{Mg}_{x} \mathrm{O}$ :Al [33], on a buffer-free CIG(SSe) absorber layer has been shown to be advantageous on the solar cell performance. In both papers, the authors argued that the improved solar cell characteristics were due to the conduction band's offset alignment on the pn-junction interface.

The importance of the heterojunction's n-type layer material, in determining the performance of the solar cell device, has been empirically demonstrated in those research works. Many of them attributed the improvement to the conduction band offset (CBO) alignment or matching between the n- and p-type layers. However, the previous works have yet to thoroughly expound the physical phenomenons that are responsible for the advantage of such band alignment in the design. Those works have also yet to illuminate the mechanism behind the harmful nature of other band alignments, as opposed to the ones recommended in the studies. Therefore, we present a fundamental study into the n-type layer of a CIG(SSe) ${ }_{2}$ solar cell in this work, in order to further understand the exact roles and design rules of this layer. Through this study, we suggest the underlying physical 
mechanisms in the device, which can explain both why certain band alignment design appear to be advantageous and others appear to be disadvantageous in the overall solar cell performance. In this study, $\mathrm{CIGS}_{2}$ material with the ideal optical band gap of $E_{g}=1.5 \mathrm{eV}$ will be used in the calculation. However, we believe that the principles introduced in this study are applicable for the material design process of CIG(SSe $)_{2}$ of any band gap. In the first part of the study, a new open-circuit voltage equation was derived by considering the effect of the current generated in the n-typelayer. This new equation served as the reference point for the maximum achievable $V_{\mathrm{OC}}$ for the rest of the work. In the second part of the study, we focused on analysing the effect of the n-type layer materials on the open-circuit voltage of the ideal band gap $\mathrm{CIGS}_{2}$ solar cell devices.

\section{Theoretical- $V_{\text {OC }}$ Equation}

To estimate the theoretical maximum- $V_{\mathrm{OC}}$ of solar cells with a particular design, several open-circuit equations have been used in solar cell design. In correspondence with the current flowing in the device, several assumptions were made to derive a theoretical $V_{\mathrm{OC}}$ equation. The first assumption is the uniformity of photon absorption across the bulk and, thus, a uniform electron-hole pairs generation rate. Another assumption is related to the width of the depletion region. The currents generated in the depletion region were neglected, since it was assumed that the depletion region was too thin to contribute a significant amount of current to the system. Based on the aforementioned assumptions, Equation (1) can be derived, where $k$ is the Boltzmann constant, $T$ is the operating temperature, $q$ is the charge, $N_{A}$ is the acceptor concentration, $n_{i}$ is the intrinsic carrier concentration, $G$ is the generation rate, and $\tau_{e}$ is the electron lifetime:

$$
V_{\mathrm{OC}}=\frac{k T}{q} \ln \frac{N_{A}}{n_{i}^{2}} G \tau_{e} .
$$

As $V_{\mathrm{OC}}$ is one of the parameters that may indicate the extent of energy availability of a solar cell, the open-circuit voltage was also defined, with respect to the quasi-Fermi energy distribution variable. In the homojunction solar cell field, such as $\mathrm{Si}$, the value of the theoretical or implied- $V_{\mathrm{OC}}$ is given as the difference between the electron's quasi-Fermi energy, $E_{F C}$, at the front contact and hole quasi-Fermi energy, $E_{F V}$, at the back contact [34]. The difference between the quasi-Fermi levels is directly related to the excited carrier concentration, $G \tau_{e}$, shown in Equation (1). Therefore, $V_{\mathrm{OC}}$ can also be estimated by using Equation (2), below:

$$
V_{\mathrm{OC}}=\frac{E_{F C}-E_{F V}}{q} .
$$

Although the assumptions are sufficiently satisfied in homojunction solar cells, heterojunction thin-film solar cells, on the other hand, do not possess such physical properties. Concerning the depletion region, the depletion layer of a heterojunction thin-film solar cell may extend well into the absorber layer, therefore allowing the photocurrent generated both in the bulk and the depletion region to contribute to the total current of the system. Besides, unlike homojunction solar cells, in which the generation can be considered uniform across the bulk, the generation rate in the bulk of heterojunction thin-film solar cells is nonuniform, with the generation rate rapidly decreased past the pn-junction interface. The generation rapidly diminished at each point further from the interface, as implied by $G(x)$, Figure 1. The high generation rate at the interface further highlights the involvement of the depletion region in determining the open-circuit voltage of a heterojunction thin-film solar cell, such as a CIGS 2 solar cell. Based on these two new assumptions, we were able to derive a new generation-dependent theoretical $V_{\text {OC }}$ equation, as written in Equation (3), where $\alpha$ is the absorption coefficient, $W$ is the depletion layer width, and $L_{e}$ is the electron diffusion length. This equation suggests that $V_{\mathrm{OC}}$ is larger than the quasi-Fermi level splitting: 


$$
V_{\mathrm{OC}}=\frac{k T}{q} \ln \frac{N_{A}}{n_{i}^{2}} G_{0} \tau_{e}\left\{\frac{1}{1+\alpha L_{e}}+\frac{e^{\alpha W}-1}{\alpha L_{e}}\right\} .
$$

The non-uniform absorption assumption, across the bulk, is represented by $\alpha L_{e}$, and the contribution of the depletion layer is represented by $e^{\alpha} W$ (Equation (3)). Additional variables, considered in Equation (3), suggest that heterojunction solar cells are theoretically able to achieve a higher open circuit voltage, compared to the homojunction solar cells. In addition, this equation is also applicable for homojunction solar cells by employing the prior assumptions, as for the derivation of Equation (1), i.e., $\alpha L_{e}<<1, L_{e}<<\alpha$, and $W$ is negligible. The accuracy of our new theoretical $V_{\mathrm{OC}}$ equation was evaluated in the following section, through a numerical calculation of a n-Window/p-Absorber solar cell structure, in an ideal condition, where the interface defect is assumed to be negligible. Next, by using the theoretical $V_{\mathrm{OC}}$ as the maximum reference value, we also explored the design rules of the n-Window / p-Absorber structure in the realistic condition to minimise the $V_{\mathrm{OC}}$ deficit in $\mathrm{CIGS}_{2}$ solar cells.

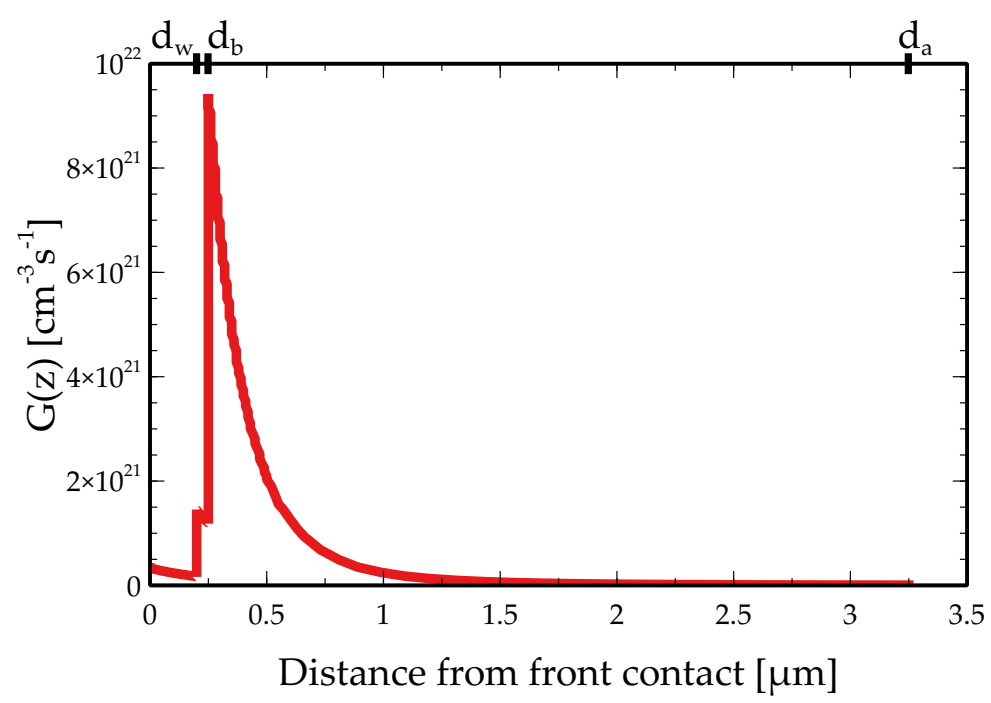

Figure 1. Generation rate profile, with respect to cell depth of a thin-film heterojunction thin-film solar cell; $\mathrm{d}_{w}, \mathrm{~d}_{b}, \mathrm{~d}_{a}$ are the respective thicknesses of the window, buffer, and absorber layers.

\section{N-Type Layer Simulation Modelling}

In this paper, two models of the device structure were simulated in the one-dimensional solar cell capacitance simulator (SCAPS-1D) [35-39], as depicted in Figure 2.

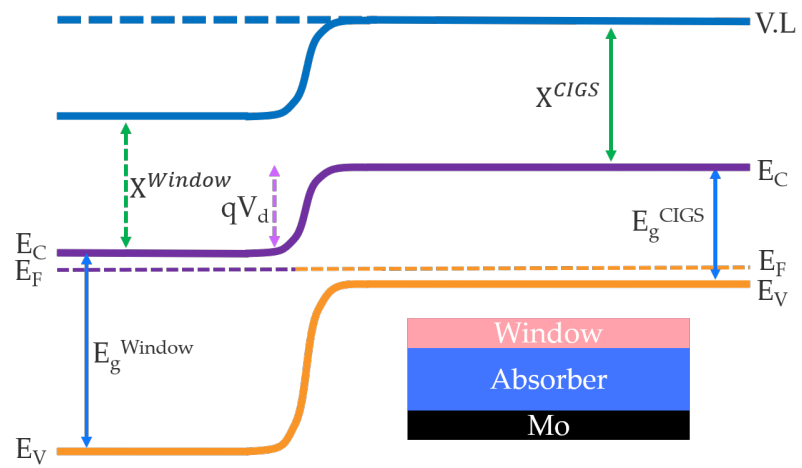

(a)

Figure 2. Cont. 


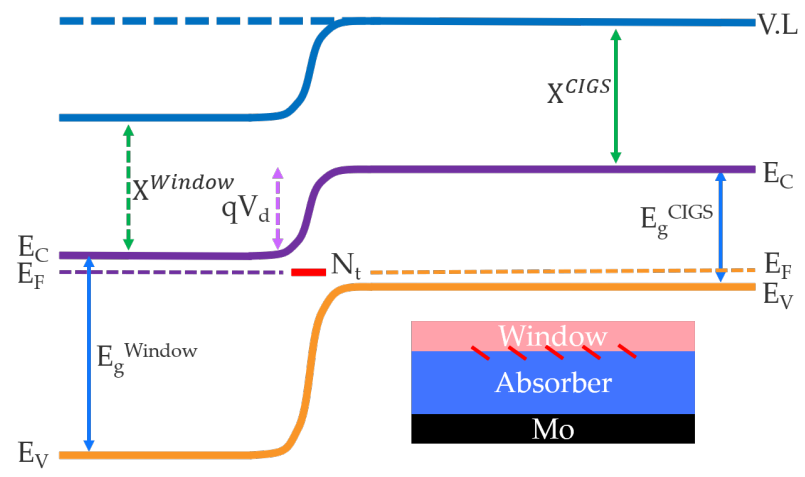

(b)

Figure 2. Illustration of $\mathrm{CIGS}_{2}$ solar cell simulation models used in the calculation for (a) window/absorber structure with ideal interface condition (Model A) and (b) window/absorber structure with non-ideal interface condition (Model B).

The first model, Model A, was a basic pn-junction solar cell with a window/absorber structure, where an arbitrary n-type material was coupled as the window layer of a wide band gap $\mathrm{CIGS}_{2}$ absorber. In this model, the interface between the layers was in an ideal condition, where no defect was present. The electron affinity of the window layer $\left(\chi^{\text {Window }}\right)$ was varied between $4.45 \mathrm{eV}$ to $4.95 \mathrm{eV}$ in this scenario, in order to simulate the effect of different n-type material coupling with $\mathrm{CIGS}_{2}$ on the open-circuit voltage. Since $V_{\mathrm{OC}}$ should reflect the maximum achievable $V_{\mathrm{OC}}$ for a wide band gap $\mathrm{CIGS}_{2}$ solar cell, the result of the calculation with Model A was also used to validate the new theoretical $V_{\text {OC }}$ equation.

A different interface condition, where a defect is present on the window/absorber interface, was considered in Model B. On the calculation using Model B, in addition to the $\chi^{\text {Window }}$ variation, the effect of different interface defect concentrations $N_{t}$ on the opencircuit voltage was considered in the simulation. The interface defect concentration was modified between $1 \times 10^{11} \mathrm{~cm}^{-2}$ and $1 \times 10^{17} \mathrm{~cm}^{-2}$ and acted as an energy trap, which initiated recombination on the interface. The energy trap at the interface was positioned in the middle of the quasi-band gap, which was formed by the conduction band of the window layer and valence band of the absorber layer. Through this second calculation, the design rule of a window layer in a more realistic condition, where an interface defect is present, was determined. The parameters used in the simulation for Models A and B were as shown in Table 1.

Table 1. SCAPS material parameter for window/absorber structure (Models A and B).

\begin{tabular}{|c|c|c|}
\hline Parameter & Window Layer & $\mathrm{CIGS}_{2}$ \\
\hline $\mathrm{d}(\mu \mathrm{m})$ & 0.20 & 3.00 \\
\hline$\chi(\mathrm{eV})$ & variable & 4.50 \\
\hline$E_{g}(\mathrm{eV})$ & 3.00 & 1.50 \\
\hline$N_{C}\left(\mathrm{~cm}^{-3}\right)$ & $2.20 \times 10^{18}$ & $2.20 \times 10^{18}$ \\
\hline$V\left(\mathrm{~cm}^{-3}\right)$ & $1.80 \times 10^{19}$ & $1.80 \times 10^{19}$ \\
\hline$\mu_{e}\left(\mathrm{~cm}^{2} \mathrm{~V}^{-1} \mathrm{~s}^{-1}\right)$ & $1.00 \times 10^{2}$ & $1.00 \times 10^{2}$ \\
\hline$\mu_{h}\left(\mathrm{~cm}^{2} \mathrm{~V}^{-1} \mathrm{~s}^{-1}\right)$ & $0.25 \times 10^{2}$ & $0.25 \times 10^{2}$ \\
\hline$N_{A}\left(\mathrm{~cm}^{-3}\right)$ & - & $1.00 \times 10^{16}$ \\
\hline$N_{D}\left(\mathrm{~cm}^{-3}\right)$ & $1.00 \times 10^{18}$ & - \\
\hline$N_{t}\left(\mathrm{~cm}^{-2}\right)$ & \multirow{3}{*}{\multicolumn{2}{|c|}{$\begin{array}{c}\text { Model } \mathrm{A}=0 \\
\text { Model B= } 1.00 \times 10^{11}-1.00 \times 10^{17} \\
\text { Model } \mathrm{A}=0 \\
\text { Model B }=1.00 \times 10^{-15} \\
\text { Model } \mathrm{A}=0 \\
\text { Model B }=1.00 \times 10^{-15}\end{array}$}} \\
\hline$\sigma_{e}\left(\mathrm{~cm}^{2}\right)$ & & \\
\hline$\sigma_{h}\left(\mathrm{~cm}^{2}\right)$ & & \\
\hline
\end{tabular}




\section{Simulation Results and Analysis}

\subsection{Maximum $V_{O C}$ and Band Diagram Analysis in Ideal Design Condition}

The calculation result using Model A is displayed in Figure 3, where the x-axis is the $\chi^{\text {Window }}$ variable, and the $y$-axis is the open-circuit voltage. Comparing the calculated values from the model and theoretical maximum $V_{\mathrm{OC}}$ from Equations (1) and (3), the ideal $V_{\mathrm{OC}}$ from the model was found to be closer to the value calculated by the new theoretical $V_{\mathrm{OC}}$ equation than the conventional equation, as indicated in the figure. The values of the variables for Equation (3) were taken from the calculation model, where $\alpha=1.00 \times 10^{5} \mathrm{~cm}^{-1}$, $W=0.5 \mu \mathrm{m}$, and $L_{e}=1.5 \mu \mathrm{m}$. This result demonstrated the accuracy of the new theoretical $V_{\mathrm{OC}}$ equation in estimating the open-circuit voltage of a heterojunction thin-film solar cell device. Thus, through the theoretical $V_{\mathrm{OC}}$ equation, we determined the maximum limit of $V_{\mathrm{OC}}$ for the $\mathrm{CIGS}_{2}$ solar cell. As previously outlined in our equation, the photon absorption in the depletion region, which includes a portion of the n-type layer and pn-junction interface, played a significant role in determining the $V_{\mathrm{OC}}$. Therefore, the establishment of a design rule for the n-type layer, that will result in the optimum performance of the solar cell, is pertinent.

To further analyse the influence of different n-type materials on the window layer, two points of interest are marked on the $x$-axis of each figure. The first point is the $\chi^{\text {Window }}$ value that is equal to the $\chi^{\text {Absorber }}$, i.e., the energy level of the conduction band of CIGS $_{2}$ or $\mathrm{E}_{\mathrm{C}_{\mathrm{CIGS}}}$, as notated in the figures. On the other hand, the $E_{\mathrm{FC}_{\mathrm{CIGS}}}$ point shows $\chi^{\text {Window }}$ value that is equal to the electron quasi-Fermi level of the $\mathrm{CIGS}_{2}$ under illumination. The carrier concentration of the window layer was high; therefore, the $\mathrm{qV}_{\mathrm{d}}$ was almost comparable to the quasi-Fermi level splitting in this condition, where $V_{d}$ refers to the diffusion potential. In Figure 4, an illustration of the band diagrams, showing the two opposite extremes in the simulation, can be observed. In the conventional homojunction solar cell, the maximum $\mathrm{V}_{\text {bias }}$ that can be applied is limited by $\mathrm{V}_{\mathrm{d}}$, which holds the capacitance at the junction. When $\chi^{\text {Window }}=4.45 \mathrm{eV}$, as drawn in Figure $4 \mathrm{a}$, the $\mathrm{qV}_{\mathrm{d}}$ is larger than the $E_{\mathrm{FC}}-E_{\mathrm{FV}}$, referring to Equation (2), open circuit condition that can be achieved with $\mathrm{V}_{\text {bias }}<\mathrm{V}_{\mathrm{d}}$. However, when the $\chi^{\text {Window }}>E_{\mathrm{FC}}$ CIGS , as depicted in Figure $4 \mathrm{~b}$, the $\mathrm{qV}_{\mathrm{d}}$ is smaller than the $E_{\mathrm{FC}}-E_{\mathrm{FV}}$, and $V_{\text {bias }}>V_{d}$ will need to be applied to fulfill the condition in Equation (2). In the case of homojunction solar cells, such condition may limit the solar cell performance.

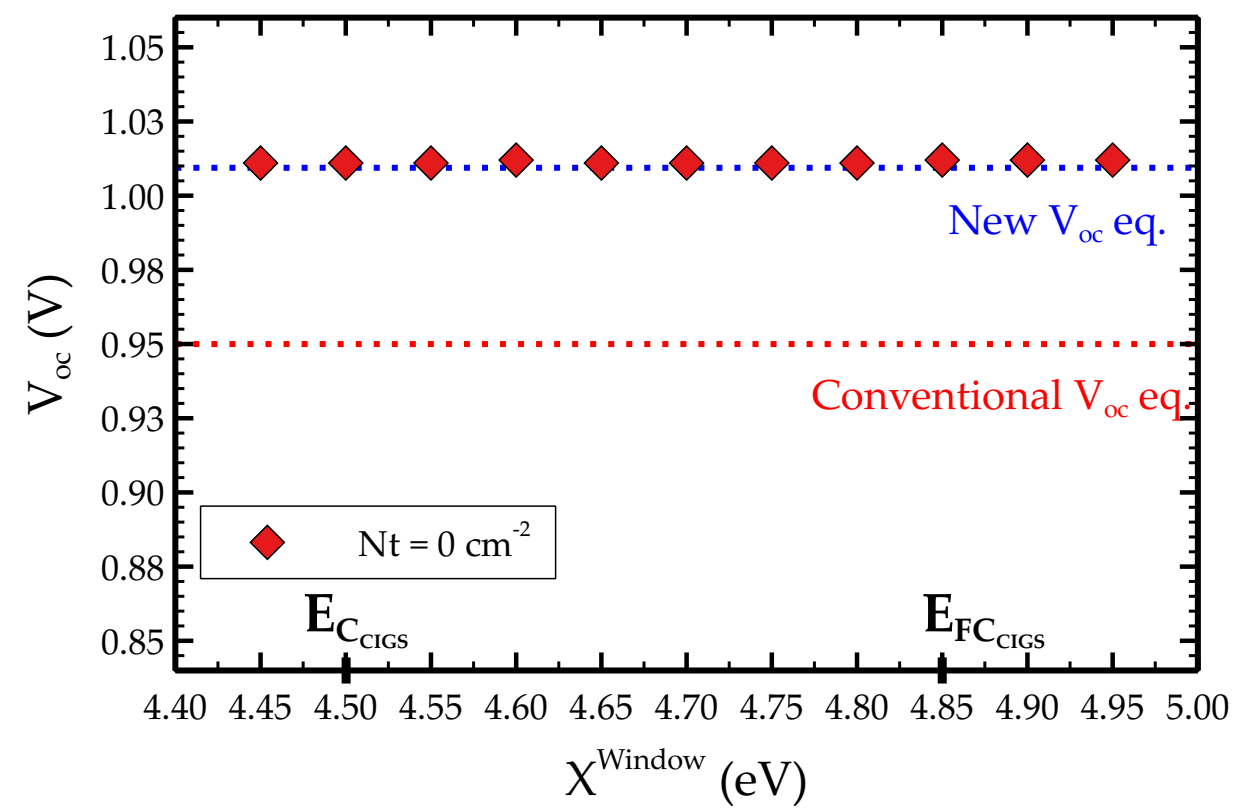

Figure 3. The effect of $\chi^{\text {Window }}$ variation on the open-circuit voltage of a $\mathrm{CIGS}_{2}$ solar cell with window/absorber structure and an ideal interface condition (Model A). 


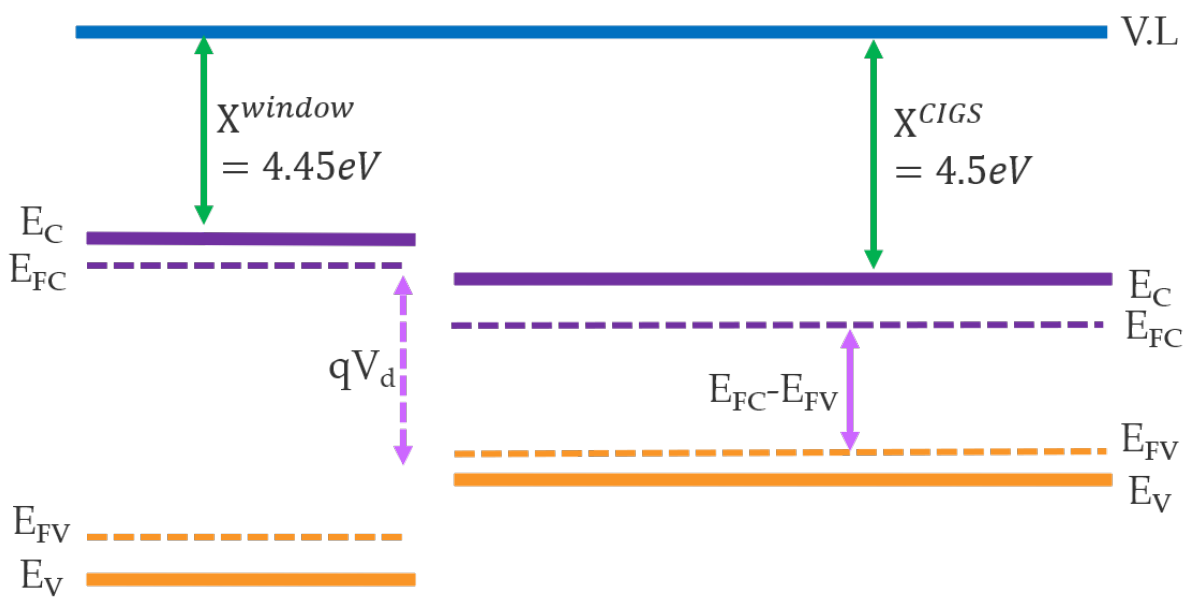

(a)
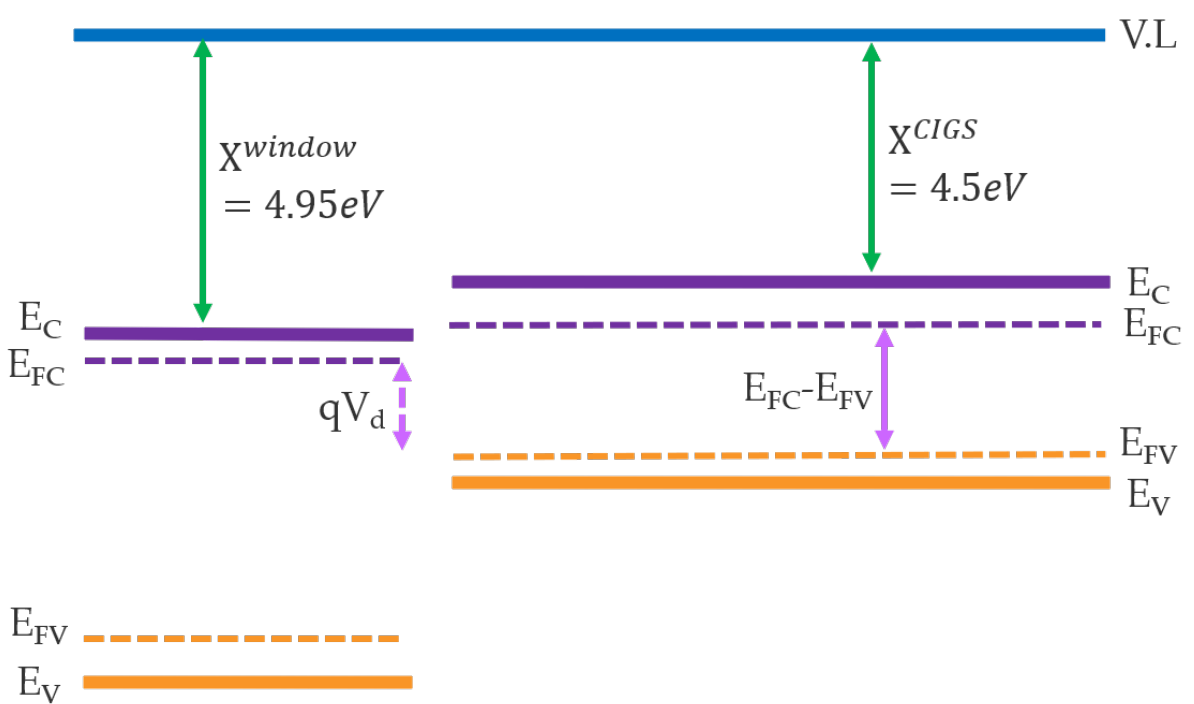

(b)

Figure 4. Illustration of the band diagram designs, with (a) $\chi^{\text {Window }}=4.45 \mathrm{eV}$ and (b) $\chi^{\text {Window }}=4.95 \mathrm{eV}$.

Figure 3 also showed that the different $\chi^{\text {Window }}$ properties in an ideal interface condition have no direct impact on the open-circuit voltage of the heterojunction solar cell. The value of $V_{\text {OC }}$ was constant at $1.02 \mathrm{eV}$ for all values of $\chi^{\text {Window }}$. Thus, in the case of $\chi^{\text {Window }}>E_{\mathrm{FC}}$ CIGS design, it can be inferred that another mechanism was sustaining the capacitance at the junction, when $V_{\text {bias }}$ higher than the diffusion potential $V_{d}$ that was applied on the device. A probable cause was deduced by analysing the shift of the energy level through the band diagrams of several band alignment designs, under the different biasing condition, as shown in Figure 5. The band diagram analysis clarified the mechanism that allowed the application $\mathrm{V}_{\text {bias }}>\mathrm{V}_{\mathrm{d}}$, which resulted in a high open-circuit voltage, even for the $\chi^{\text {Window }}>E_{\mathrm{FC}}$ CIGS design.

In Figure 5, the energy band diagrams of the two different window/absorber designs were contrasted. On the left-hand side (Figure 5a,c,e,g), the shifts of the the conduction $\mathrm{E}_{\mathrm{C}}$ and valence bands $\mathrm{E}_{\mathrm{V}}$, as well as the quasi-Fermi distribution of the electrons $\left(E_{\mathrm{FC}}\right)$ and holes $\left(E_{\mathrm{FV}}\right)$ of the device with $\chi^{\text {Window }}=4.45 \mathrm{eV}$, at various biasing levels under illumination, were compiled. Whereas, on the right-hand side (Figure $5 b, \mathrm{~d}, \mathrm{f}, \mathrm{h}$ ), similar parameters of the $\chi^{\text {Window }}=4.95 \mathrm{eV}$ device, in the same biasing levels, were compiled. Figure $4 \mathrm{a}, \mathrm{b}$ illustrated the band alignment models of the $\chi^{\text {Window }}=4.45 \mathrm{eV}$ and $\chi^{\text {Window }}=4.95 \mathrm{eV}$ 
designs, respectively. The four biasing conditions under illumination that were chosen in Figure 5 were the $V_{\text {bias }}=0 \mathrm{~V}$ and $\mathrm{V}_{\text {bias }}=0.82 \mathrm{~V}$, which were equal to the diffusion potential $\mathrm{V}_{\mathrm{d}}$ of the $\chi^{\text {Window }}=4.95 \mathrm{eV}$ design, $\mathrm{V}_{\text {bias }}=0.95 \mathrm{~V}$, which was equal to the initial quasi-Fermi level difference of both designs and $\mathrm{V}_{\text {bias }}=1.02 \mathrm{~V}$, where both devices were shown to reach the open-circuit condition, as suggested by Figure 3.

As previously mentioned, in the case of a homojunction solar cell, such as $\mathrm{Si}$, the diffusion potential $\mathrm{V}_{\mathrm{d}}$ is sustained by the capacitance at the depletion region. The open-circuit condition was achieved when there was no gradient present at the interface of the currentcontributing carrier quasi-Fermi distribution or, in other words, the electron quasi-Fermi distribution. Due to the heterogeneous nature of the materials, such an equilibrium condition may not be achieved at $\mathrm{V}_{\text {bias }}<\mathrm{V}_{\mathrm{d}}$, in the case of heterojunction thin-film solar cells. In the example given on Figure $5 \mathrm{~d}$, biasing levels equal to $V_{d}$ of the $\chi^{\text {Window }}=4.95 \mathrm{eV}$ design at $\mathrm{V}_{\text {bias }}=0.82 \mathrm{~V}$ were applied to Model A. The $\mathrm{V}_{\mathrm{d}}=\mathrm{V}_{\text {bias }}$ condition was represented by the lack of conduction and valence band bending at the junction. On the other hand, band-bending was observable in Figure $5 c$, when the same biasing level applied to the $\chi^{\text {Window }}=4.45 \mathrm{eV}$ design, since $\mathrm{V}_{\mathrm{d}}>\mathrm{V}_{\text {bias }}$ for this condition. However, a gradient was still observable at the electron's quasi-Fermi distribution, which indicated a current flow, suggesting the open-circuit condition was yet to be achieved. It was true for both designs, but unusual in the case of the $\chi^{\text {Window }}=4.95 \mathrm{eV}$ design. Upon the application of higher $\mathrm{V}_{\text {bias, }}$, spikes and notches were formed on the conduction band and valence band, due to the majority carriers accumulation on their respective layers at the interface, as depicted in Figure $5 \mathrm{f}, \mathrm{h}$. In the case when $\mathrm{V}_{\text {bias }}$ was equal to the conventional theoretical $V_{\mathrm{OC}}$ at $\mathrm{V}_{\text {bias }}=0.95 \mathrm{~V}$, the open-circuit condition was not yet reached. The open-circuit condition was finally obtained when $\mathrm{V}_{\text {bias }}=1.02 \mathrm{~V}$. In contrast with Si solar cell, where the bias voltage was sustained by capacitance at the depletion region, the accumulation of the majority carriers at the interface enabled heterojunction thin-film solar cell, such as $\mathrm{CIGS}_{2}$, to achieve higher $V_{\mathrm{OC}}$ than their homojunction counterpart. This finding also underlined the influence of the interface condition in determining the optimum n-type layer design.

$\chi^{\text {Window }}=4.45 \mathrm{eV}$

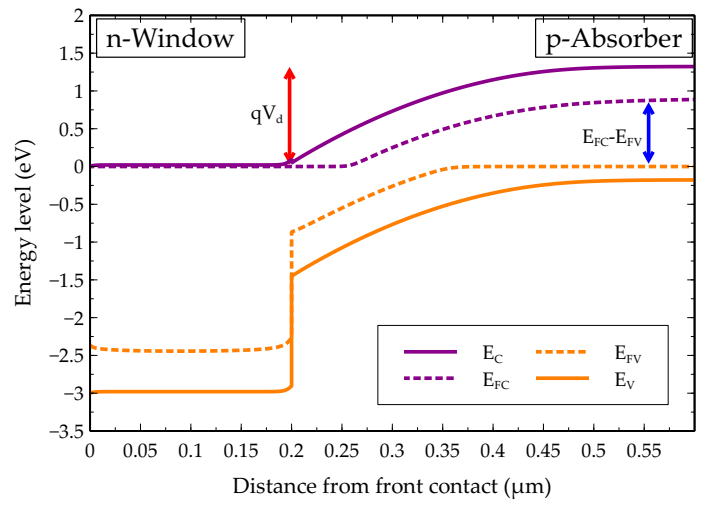

(a) $\chi^{\text {Window }}=4.95 \mathrm{eV}$

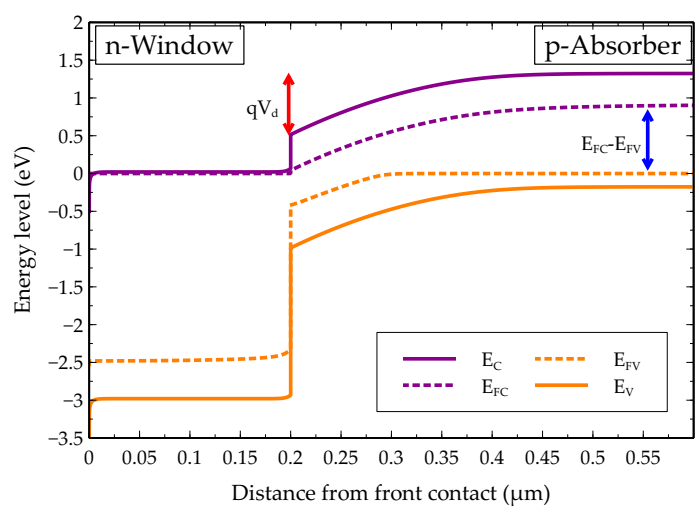

(b)

Figure 5. Cont. 


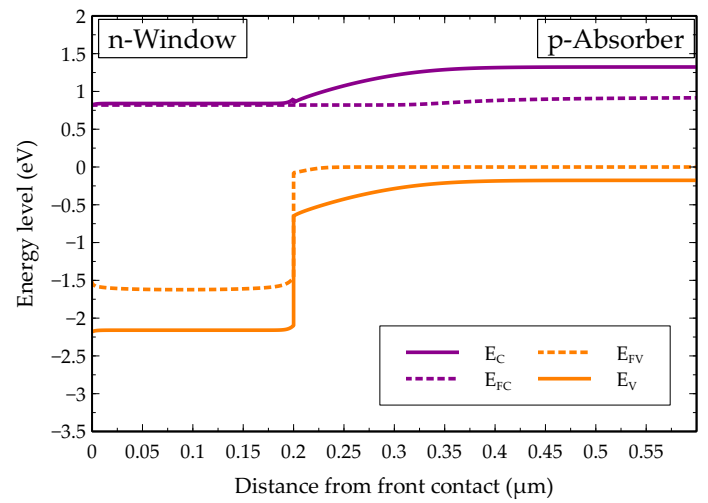

(c)

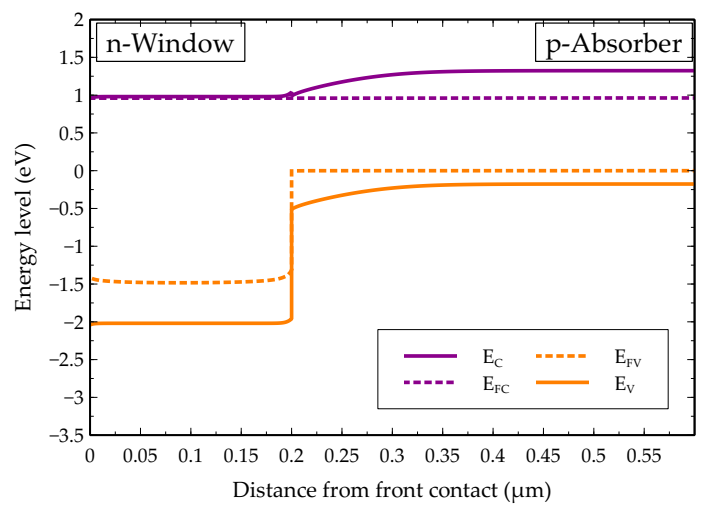

(e)

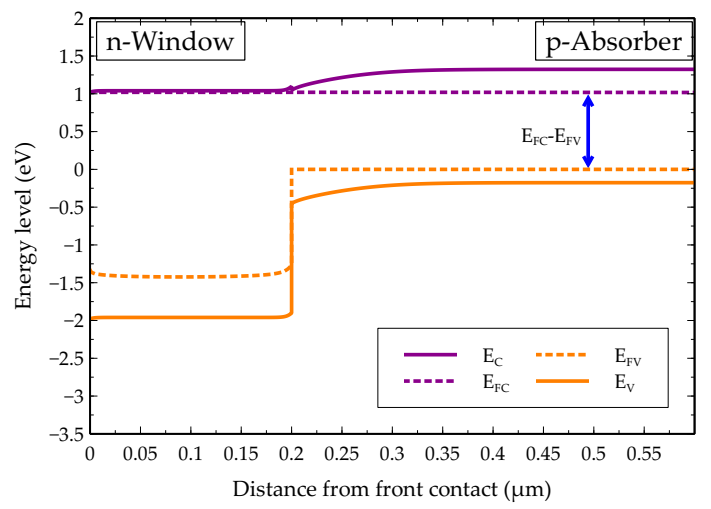

(g)

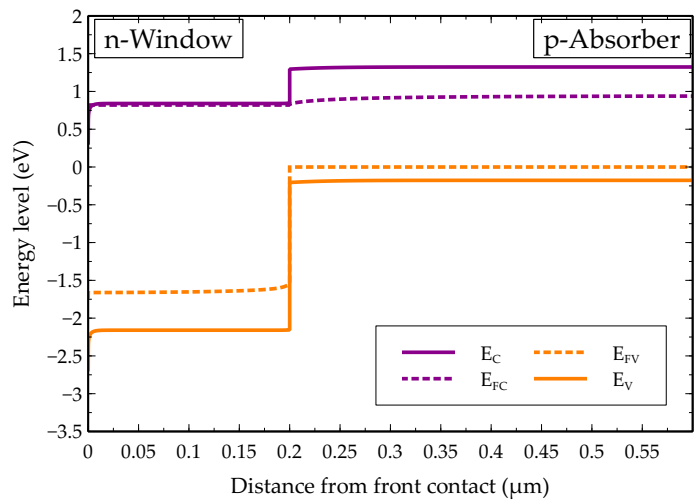

(d)

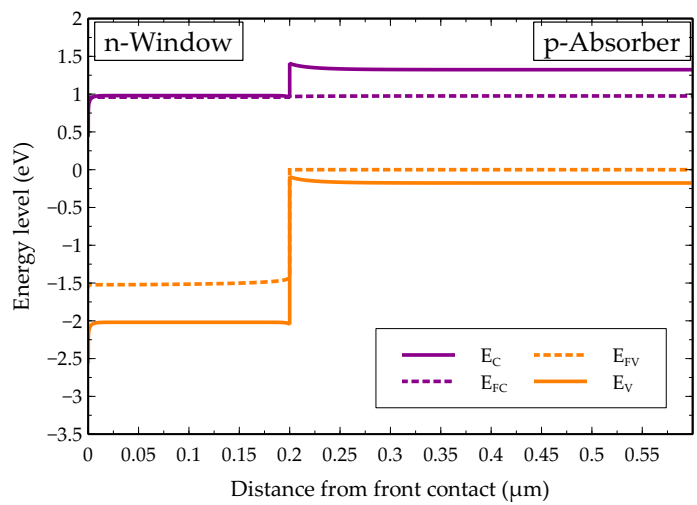

(f)

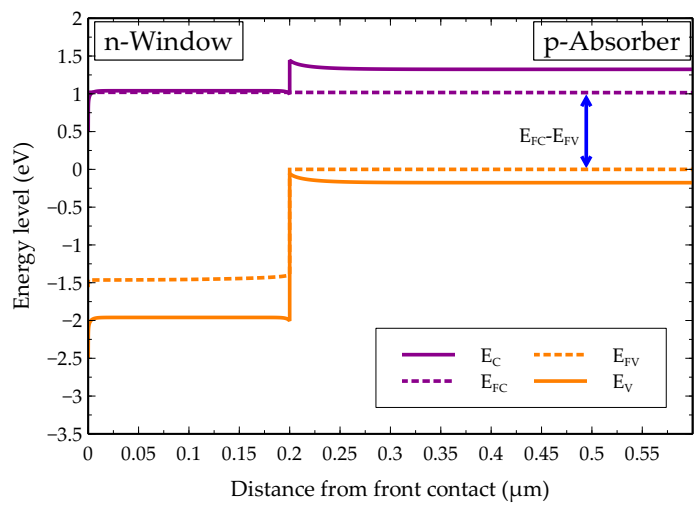

(h)

Figure 5. The band diagrams under illumination, calculated from Model A for $\chi^{\text {Window }}=4.45 \mathrm{eV}$ and $\chi^{\text {Window }}=4.95 \mathrm{eV}$ window designs in various biasing conditions; $(\mathbf{a}, \mathbf{b})$ are for $\mathrm{V}_{\text {bias }}=0 \mathrm{~V}$, $(\mathbf{c}, \mathbf{d})$ are for $\mathrm{V}_{\text {bias }}=0.82 \mathrm{~V},(\mathbf{e}, \mathbf{f})$ are for $\mathrm{V}_{\text {bias }}=0.95 \mathrm{~V}$, and $(\mathbf{g}, \mathbf{h})$ are for $\mathrm{V}_{\text {bias }}=1.02 \mathrm{~V}$.

\subsection{The Roles of N-Type Layer in Realistic Design Condition}

A similar simulation scenario, applied in Model B, revealed the significance of the interface condition in establishing a boundary of the appropriate n-type materials that would be suitable for window layer application. From Figure 6, the general design rule for a window layer can be inferred that the defect concentration on the interface would determine the range of acceptable n-type material coupling candidates in $\mathrm{CIGS}_{2}$ solar cell design. The calculation result suggested that to attain high $V_{\mathrm{OC}}$, a broader range 
of alternative n-type material could be allowed in devices with lower interface defect concentration. In contrast, devices with higher $N_{t}$ would require more precise design work to theoretically gain the estimated theoretical $V_{\mathrm{OC}}$, due to the limited option in the n-type material choices.

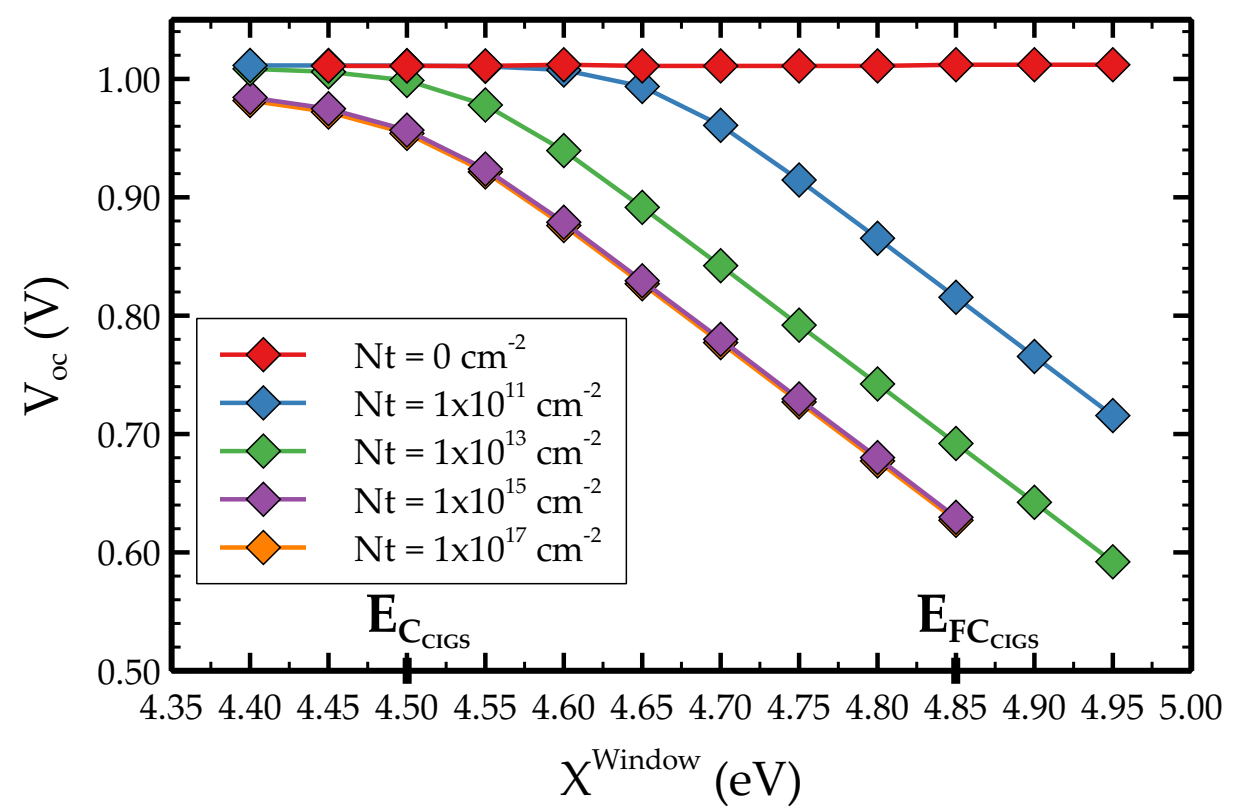

Figure 6. The effect of $\chi^{\text {Window }}$ variation on the open-circuit voltage of a $\mathrm{CIGS}_{2}$ solar cell with window/absorber structure and non-ideal interface condition for various $N_{t}$ value (Model B).

\subsubsection{N-Type Layer as Interface Passivation}

The relationship between the n-type layer and interface defect can be explained by considering the phenomenon that occurred in Figure 5, particularly regarding the majority carriers accumulation upon $\mathrm{V}_{\text {bias }} \approx \mathrm{V}_{\mathrm{d}}$. Whereas, the accumulation of the majority carriers at the pn-junction interface immediately increases the recombination probability. In Model A, where the interface defect was assumed to be absent, the recombination did not occur, even in the most extreme case of cliff structure, with the $\chi^{\text {Window }}=4.95 \mathrm{eV}$ material design.

However, in the case of the non-ideal interface condition in Model B, the increased recombination probability, due to the majority carrier accumulation at the interface, played a significant role in determining the $V_{\mathrm{OC}}$ of the solar cell. In this model, the interface defect acted as an energy trap that triggered the trap-assisted recombination mechanism upon the accumulation of electrons and holes at the interface. Another variable that affects the recombination probability is the defect concentration $N_{t}$. A combination of high carrier accumulation and high $N_{t}$ will result in the highest recombination probability. Therefore, the designs that use materials $\chi^{\text {Window }} \geq \chi^{\text {Absorber }}$ are at a disadvantage, compared to the designs that use low electron affinity materials, since the use of low electron affinity material for the window layer will reduce the electron accumulation on the conduction band, as illustrated in Figure $5 \mathrm{~g}$. From this point of view, the n-type layer serves as a passivation layer and the solar cells with the latter design were still able to maintain high $V_{\mathrm{OC}}$ even at very high defect concentration while the devices with high electron affinity n-type materials were severely impacted by the high $N_{t}$.

\subsubsection{N-Type Layer as Selective Electron Contact}

From the perspective of the carrier collection, another impact of the n-type layer material design was considered. In [40], Würfel et al. introduced the concept of conductivity for specific carriers at each contact as the driving source behind charge separation in pnjunction solar cells, instead of the built-in potential or diffusion potential $\mathrm{V}_{\mathrm{d}}$. The front contact (in this case, the n-type layer) is said to be selective for electrons when the layer 
has high conductivity for electrons and low conductivity for holes. Meanwhile, the back contact is said to be selective for holes when the layer has high conductivity for holes and low conductivity for electrons. A selective contact will attract the target carrier and repel the opposite carrier to avoid recombination prior to carrier collection. As the conductivity is a product of elemental charge, carrier concentration, and mobility, the only controllable variable that can be achieved through material design process is the carrier concentration. Therefore, a large carrier concentration ratio, in favour of the target carriers, which are electrons in the n-type layer, is essential to design a contact with high selectivity. Up to date, two types of selectivity models have been proposed by Brendel et al. in [41] and Roe et al. in [42]. In [43], Rau et al. demonstrated the relationship between contact selectivity and built-in potential or diffusion potential $\mathrm{V}_{\mathrm{d}}$.

In the case of our work, the contact selectivity of the n-type layer was controlled by adjusting the minority carrier concentration $(p)$ at the interface, through the selection of appropriate electron affinity for the heterojunction n-type material. As shown in Figure 7, compared to the low electron affinity material with $\chi^{\text {Window }}=4.45 \mathrm{eV}$, the $\mathrm{V}_{\mathrm{d}}$ for the device with $\chi^{\text {Window }}=4.95 \mathrm{eV}$ was smaller, resulting in $p^{\chi=4.95}>p^{\chi=4.45}$. Assuming the same majority carrier concentration for the n-type layer, if selectivity $S$ is defined as the ratio between the majority and minority carriers, then the comparison between the electron contact selectivity $\left(S_{n}\right)$ of these particular designs was $S_{n}^{\chi=4.95}<S_{n}^{\chi=4.45}$. In other words, the n-type layer with lower electron affinity material, with respect to the absorber, served as a more effective electron contact from the carrier selectivity perspective. The high $V_{\mathrm{OC}}$ was able to be achieved and maintained, even at high interface defect concentration, since the contact was able to efficiently collect electrons, while repelling holes at the same time.

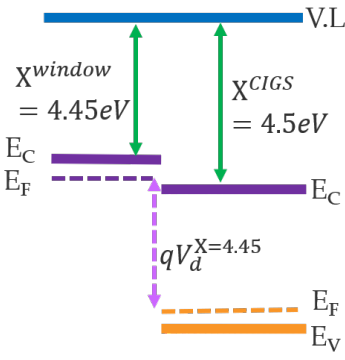

$\mathrm{E}_{\mathrm{V}}$
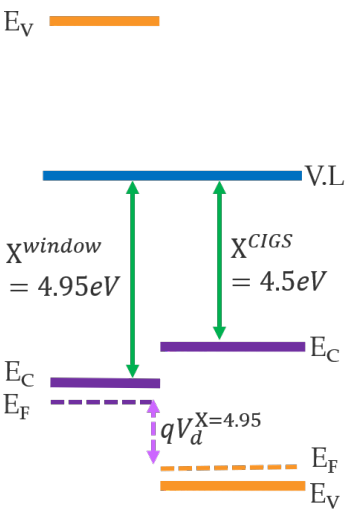

$\mathrm{E}_{\mathrm{v}}$

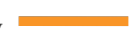

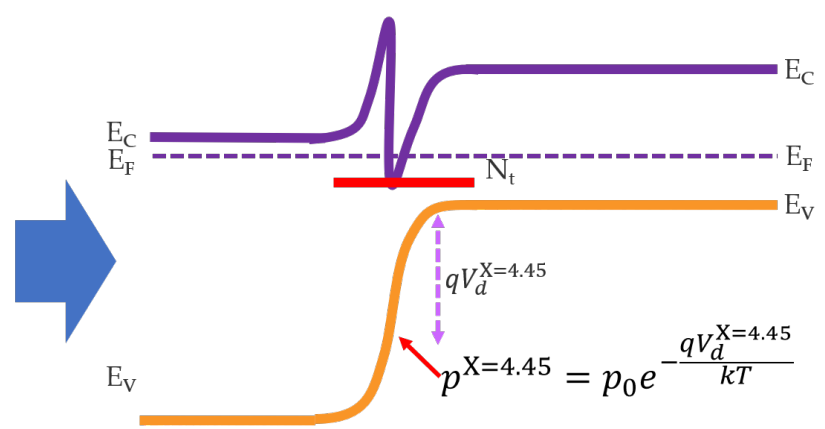

(a)

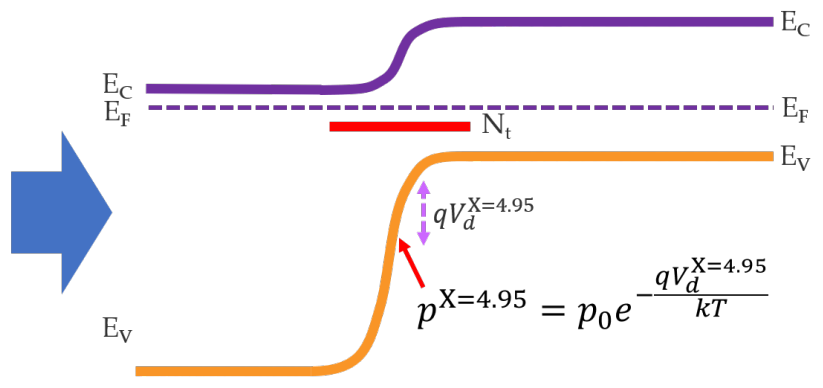

(b)

Figure 7. Illustration of the diffusion potential $V_{d}$ effect on the hole concentration at the interface in devices with (a) low electron affinity and (b) high electron affinity. 


\subsection{N-Type Layer Dependence on the $\mathrm{Ga}$ - and S-Content in the $\mathrm{CIG}(\mathrm{SSe})_{2}$ Absorber Layer}

As has been expounded up to this point, this study was approached from the perspective of CIG(SSe) $)_{2}$ chalcopyrite material as the absorber layer of a heterojunction solar cell, especially the wide band gap CIG(SSe $)_{2}$ material. An absorber layer with a band gap close to the ideal single-junction solar cell band gap (i.e., $E_{g}=1.5 \mathrm{eV}$ ) was used in the calculation. However, the findings, regarding the roles and design rules of the n-type layer, are applicable beyond the particular absorber that was used in the calculation. These findings are especially important, regarding the $\mathrm{CIG}(\mathrm{SSe})_{2}$ heterojunction solar cell, considering the adjustable band gap nature of the material. In this work, it can be argued that it is theoretically probable to optimise any type of CIG(SSe) $)_{2}$ solar cells by using the appropriate n-type material. Such optimisation will also allow a buffer-free design, which is advantageous from the manufacturing perspective.

In Figure 8, the position of the CIG(SSe $)_{2}$ absorber material's electron affinities, relative to the vacuum level, were mapped for different $\mathrm{Ga}$ and $\mathrm{S}$ concentrations, based on the calculation work performed by Maeda et al. in [44]. The band gaps and electron affinities of certain absorber materials with various $\mathrm{Ga} /[\mathrm{Ga}+\mathrm{In}]$ and $\mathrm{S} /[\mathrm{S}+\mathrm{Se}]$ ratios, as also marked in Figure 8, are calculated in Table 2. In both the table and figure, the four interest points notated are: (A) wide band gap pure-selenide $\mathrm{CIGSe}_{2}$ with band gap close to the ideal single-junction solar cell band gap, (B) wide band gap pure-selenide CIGSe ${ }_{2}$ with band gap suitable for top cell tandem application, (C) wide band gap pure-sulfide $\mathrm{CIGS}_{2}$ with band gap close to the ideal single-junction solar cell band gap, and (D) wide band gap pure-sulfide $\mathrm{CIGS}_{2}$ with band gap suitable for top cell tandem application.

Table 2. Examples of CIG(SSe) 2 absorber materials with different Ga and S composition, and the changing electron affinity reference for the n-type layer.

\begin{tabular}{ccccc}
\hline & \multicolumn{2}{c}{ CIGSe $_{2}$} & \multicolumn{2}{c}{ CIGS $_{2}$} \\
& S/[S + Se] $=\mathbf{0}$ & \multicolumn{2}{c}{ S/[S + Se] = 1 } \\
\hline & $A$ & $B$ & $C$ & $D$ \\
\hline $\mathrm{Ga} /[\mathrm{Ga}+\mathrm{In}]$ & 0.7 & 1.0 & 0.0 & 0.4 \\
$E_{g}(\mathrm{eV})$ & 1.37 & 1.65 & 1.45 & 1.75 \\
$\chi^{\text {absorber }}(\mathrm{eV})$ & 3.83 & 3.53 & 3.96 & 3.74 \\
\hline
\end{tabular}

From the figure and table, it can be understood that the electron affinity significantly shifted to a lower position with the increase of Ga concentration in the compound. The same effect can also be observed by the addition of $\mathrm{S}$ concentration but at a lower degree. Thus, from the mapping and our calculation results, it can be understood that the band gap control, using Ga and S for CIG(SSe) $)_{2}$, not only affects the band gap (e.g., resulting in a wider band gap material) but also the reference point for the electron affinity that is necessary for the pn-junction optimum coupling design to maintain a high $V_{\mathrm{OC}}$, i.e., a ntype material that has wide optical band gap and electron affinity lower than the absorber's reference point to perform as passivation and electron contact layers. Regarding the $\mathrm{CIG}(\mathrm{SSe})_{2}$ solar cell, in terms of a single-junction solar cell application, it can be understood that the ideal $\chi^{\text {Window }}$ will be in the range of 3.75-3.96 eV, while for the tandem solar cell application, the ideal $\chi^{\text {Window }}$ will be in the range of 3.53-3.74 eV. 


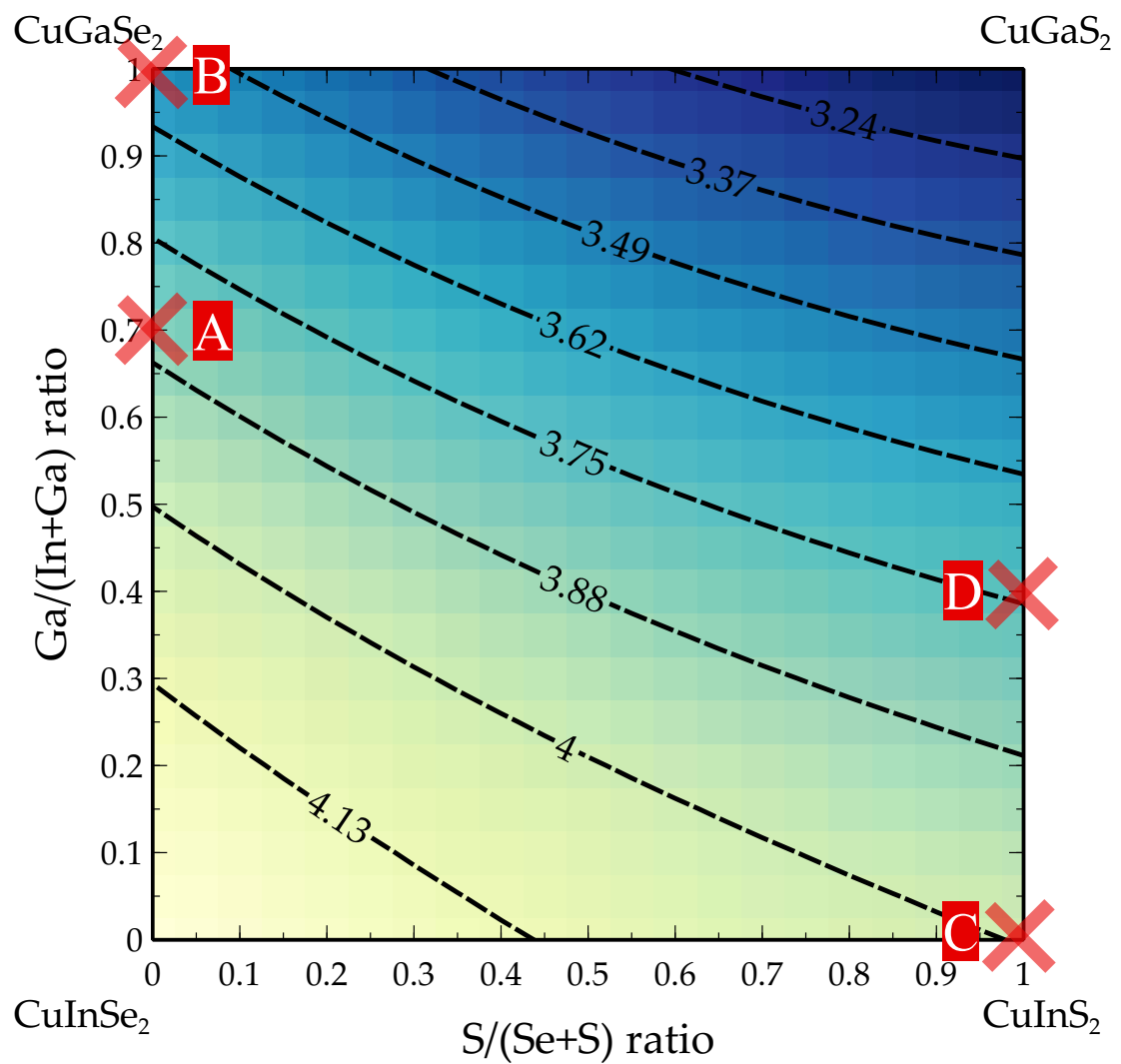

Figure 8. Mapping of the $\mathrm{CIG}(\mathrm{SSe})_{2}$ absorber's electron affinity, relative to the vacuum level for various $\mathrm{Ga} /[\mathrm{Ga}+\mathrm{In}]$ and $\mathrm{S} /[\mathrm{S}+\mathrm{Se}]$ ratios.

\section{Conclusions}

Wide band gap CIG(SSe) ${ }_{2}$ has the potential to be a top cell for tandem solar cell applications. Most of the previous studies focused on Ga-rich, pure-selenide CIGSe 2 absorber material, which has high recombination issue. Some works were done on puresulfide $\mathrm{CIGS}_{2}$ absorber material. In those works, a similar technique and n-type material pairing, conventionally applied for narrow-band gap $\mathrm{CIGSe}_{2}$ solar cells, was assumed. Based on the literature reviews, experimental results showed that an alternative n-type material is needed to achieve high-efficiency wide band gap CIGS $_{2}$.

In this work, we derived a new generation-dependent theoretical $V_{\mathrm{OC}}$ equation for heterojunction thin-film solar cells. This new equation emphasised the role of the depletion region in determining the attainable $V_{\mathrm{OC}}$ for a particular solar cell design. Through the equation, we got an accurate approximation to the highest $V_{\mathrm{OC}}$ limit for our $\mathrm{CIGS}_{2}$ solar cell design. Since the n-type layers and junction interface are crucial aspects of the depletion region, in the next part of the paper, we investigated the particular roles and design rules of the n-type layers (i.e., the window and buffer layers) of a typical wide band gap CIGS $_{2}$ solar cell. The design rules can be ascertained, with the utmost confidence, by using the accurate $V_{\mathrm{OC}}$ estimation, calculated through the theoretical $V_{\mathrm{OC}}$ equation.

An absorber layer, with a band gap close to the ideal single-junction solar cell, was considered in the calculation. In such a case, based on the window/absorber structure, we observed that the theoretical $V_{\mathrm{OC}}$ was attainable in all simulated conditions $\left(\chi^{\text {Window }}=4.45-4.95 \mathrm{eV}\right)$ when the interface was in an ideal condition, i.e., low-defect condition. However, in the more realistic device conditions, where interface defect was present, the n-type material design had a crucial role in determining the attainable $V_{\mathrm{OC}}$ for each 
device. Based on the calculation, an n-type material with low electron affinity, respective to the absorber layer, is preferable for the buffer-free $\mathrm{CIGS}_{2}$ solar cell application. This result demonstrated that the $n$-type layer performs both interface passivating and selective electron contact functions. By considering these perspectives, and adopting n-type material with the appropriate electron affinity in the material design process, high $V_{\mathrm{OC}}$ is attainable, even at high interface defect concentration conditions.

Author Contributions: Conceptualization, A.Y.; methodology, A.Y.; software, D.E.; validation, D.E. and A.Y.; formal analysis, D.E. and A.Y.; investigation, D.E. and A.Y.; resources, D.E. and A.Y.; data curation, D.E.; writing—original draft preparation, D.E.; writing—review and editing, D.E., K.N. and A.Y.; visualization, D.E.; supervision, A.Y.; project administration, K.N. and A.Y.; funding acquisition, A.Y. All authors have read and agreed to the published version of the manuscript.

Funding: This paper was based on results obtained from a project commissioned by the New Energy and Industrial Technology Developement Organization (NEDO) and this work was also supported by JSPS KAKENHI Grant Number JP20H02636.

Institutional Review Board Statement: Not applicable.

Informed Consent Statement: Not applicable.

Data Availability Statement: The data that support the findings of this study are available from the corresponding author, D.E., upon reasonable request.

Conflicts of Interest: The authors declare no conflict of interest associated with this manuscript.

\section{References}

1. Paulson, P.; Birkmire, R.; Shafarman, W. Optical characterization of $\mathrm{CuIn}_{1-x} \mathrm{Ga}_{x} \mathrm{Se}_{2}$ alloy thin films by spectroscopic ellipsometry. J. Appl. Phys. 2003, 94, 879-888. [CrossRef]

2. Orgassa, K. Coherent Optical Analysis of the $\mathrm{ZnO} / \mathrm{CdS} / \mathrm{Cu}(\mathrm{In}, \mathrm{Ga}) \mathrm{Se}_{2}$ Thin Film Solar Cell; Shaker: Baden-Württemberg, Stuttgart, 2004.

3. Coutts, T.J.; Ward, J.S.; Young, D.L.; Emery, K.A.; Gessert, T.A.; Noufi, R. Critical issues in the design of polycrystalline, thin-film tandem solar cells. Prog. Photovolt. Res. Appl. 2003, 11, 359-375. [CrossRef]

4. Meillaud, F.; Shah, A.; Droz, C.; Vallat-Sauvain, E.; Miazza, C. Efficiency limits for single-junction and tandem solar cells. Sol. Energy Mater. Sol. Cells 2006, 90, 2952-2959. [CrossRef]

5. Spiess, H.W.; Haeberlen, U.; Brandt, G.; Räuber, A.; Schneider, J. Nuclear magnetic resonance in IB-III-VI2 semiconductors. Phys. Status Solidi B 1974, 62, 183-192. [CrossRef]

6. Zunger, A.; Jaffe, J. Structural origin of optical bowing in semiconductor alloys. Phys. Rev. Lett. 1983, 51, 662. [CrossRef]

7. Nakamura, M.; Tada, K.; Kinoshita, T.; Bessho, T.; Nishiyama, C.; Takenaka, I.; Kimoto, Y.; Higashino, Y.; Sugimoto, H.; Segawa, H. Perovskite/CIGS spectral splitting double junction solar cell with $28 \%$ power conversion efficiency. Iscience 2020, $23,101817$. [CrossRef]

8. Hamtaei, S.; Brammertz, G.; Meuris, M.; Poortmans, J.; Vermang, B. Dominant Processing Factors in Two-Step Fabrication of Pure Sulfide CIGS Absorbers. Energies 2021, 14, 4737. [CrossRef]

9. Rühle, S. Tabulated values of the Shockley-Queisser limit for single junction solar cells. Sol. Energy 2016, 130, 139-147. [CrossRef]

10. Sze, S.; Ng, K. Physics of Semiconductor Devices; Wiley: New York, NY, USA, 2006.

11. Nishimura, T.; Kasashima, S.; Hirai, Y.; Kurokawa, Y.; Yamada, A. Fabrication of Cu(In,Ga)(Se) ${ }_{2}$ solar cells with a single graded band profile. Phys. Status Solidi B 2015, 252, 1235-1238. [CrossRef]

12. Hirai, Y.; Hidaka, Y.; Kurokawa, Y.; Yamada, A. Improvement of the Band Profile of Cu(In,Ga)(Se) ${ }_{2}$ Solar Cells with High-Ga Content Prepared Using a Five-Stage Method. Jpn. J. Appl. Phys. 2012, 51, 10NC03. [CrossRef]

13. Hirai, Y.; Suzuki, R.; Kurokawa, Y.; Yamada, A. Numerical simulation about effects of bandgap grading in $\mathrm{Cu}(\mathrm{In}, \mathrm{Ga})(\mathrm{Se})_{2}$ with a bandgap of $1.4 \mathrm{eV}$ on solar cell performance. In Proceedings of the 2013 IEEE 39th Photovoltaic Specialists Conference (PVSC), Tampa, FL, USA, 16-21 June 2013; pp. 3307-3309.

14. Chung, C.H. Method to Determine the Recombination Characteristics of Minority Carriers in Graded-Band-Gap Solar Cells. Phys. Rev. Appl. 2019, 12, 24060. [CrossRef]

15. Za'abar, F.; Zuhdi, A.W.M.; Bahrudin, M.S.; Abdullah, S.F.; Hasani, A.H. Numerical modelling of graded bandgap CIGS solar cell for performance improvement. In Proceedings of the 2019 Electron Devices Technology and Manufacturing Conference (EDTM), Singapore, 12-15 March 2019; pp. 469-471.

16. Sadono, A.; Hino, M.; Nakada, K.; Yamada, A. Effect of an additional Cu-deficient layer deposition on alkali treated Cu(In,Ga)(Se) 2 solar cells deposited at low temperature. Sol. Energy Mater. Sol. Cells 2018, 184, 67-72. [CrossRef]

17. Sadono, A.; Ogihara, T.; Hino, M.; Yamamoto, K.; Yamada, A. Peeled-off flexible Cu(In,Ga)(Se) 2 solar cells and Na diffusion effects on cell performances. Electron. Mater. Lett. 2016, 12, 494-498. [CrossRef] 
18. Nishimura, T.; Toki, S.; Sugiura, H.; Nakada, K.; Yamada, A. Effect of Cu-deficient layer formation in Cu(In,Ga)Se 2 solar-cell performance. Prog. Photovolt. Res. Appl. 2018, 26, 291-302. [CrossRef]

19. Ogihara, T.; Sadono, A.; Nishimura, T.; Nakada, K.; Yamada, A. Control of valence band offset of Cu(In,Ga)Se 2 solar cells with single-graded band profile. Jpn. J. Appl. Phys. 2017, 56, 062301. [CrossRef]

20. Ji, S.; Hayakawa, T.; Suyama, N.; Nakada, K.; Yamada, A. Enhancement of $\mathrm{Cu}(\mathrm{In}, \mathrm{Ga})(\mathrm{Se})_{2}$ solar cells efficiency by controlling the formation of Cu-deficient layer. Jpn. J. Appl. Phys. 2020, 59, 041003. [CrossRef]

21. Wang, Y.; Muryobayashi, T.; Nakada, K.; Li, Z.; Yamada, A. Correlation between carrier recombination and valence band offset effect of graded Cu(In,Ga)Se 2 solar cells. Sol. Energy Mater. Sol. Cells 2019, 201, 110070. [CrossRef]

22. Nakamura, M.; Yamaguchi, K.; Kimoto, Y.; Yasaki, Y.; Kato, T.; Sugimoto, H. Cd-free Cu(In,Ga)(S,Se) 2 thin-film solar cell with record efficiency of 23.35\%. IEEE J. Photovolt. 2019, 9, 1863-1867. [CrossRef]

23. Sugimoto, H.; Hiroi, H.; Iwata, Y.; Yamada, A. Recent progress in high efficiency pure sulfide CIGS solar cells. In Proceedings of the 27th International Photovoltaic Science and Engineering Conference, Kyoto, Japan, 12-17 November 2017.

24. Gloeckler, M.; Sites, J. Efficiency limitations for wide-band-gap chalcopyrite solar cells. Thin Solid Film 2005, 480, 241-245. [CrossRef]

25. Wei, S.H.; Zunger, A. Calculated natural band offsets of all II-VI and III-V semiconductors: Chemical trends and the role of cation d orbitals. Appl. Phys. Lett. 1998, 72, 2011-2013. [CrossRef]

26. Larsson, F.; Nilsson, N.S.; Keller, J.; Frisk, C.; Kosyak, V.; Edoff, M.; Törndahl, T. Record 1.0 V open-circuit voltage in wide band gap chalcopyrite solar cells. Prog. Photovolt. Res. Appl. 2017, 25, 755-763. [CrossRef]

27. Hiroi, H.; Iwata, Y.; Adachi, S.; Sugimoto, H.; Yamada, A. New world-record efficiency for pure-sulfide Cu(In,Ga)S ${ }_{2}$ thin-Film solar cell with Cd-free buffer layer via KCN-free process. IEEE J. Photovolt. 2016, 6, 760-763. [CrossRef]

28. Minemoto, T.; Negami, T.; Nishiwaki, S.; Takakura, H.; Hamakawa, Y. Preparation of $\mathrm{Zn}_{1-x} \mathrm{Mg}_{x} \mathrm{O}$ films by radio frequency magnetron sputtering. Thin Solid Film 2000, 372, 173-176. [CrossRef]

29. Minemoto, T.; Hashimoto, Y.; Satoh, T.; Negami, T.; Takakura, H.; Hamakawa, Y. Cu(In,Ga)Se 2 solar cells with controlled conduction band offset of window/Cu(In,Ga)Se layers. J. Appl. Phys. 2001, 89, 8327-8330. [CrossRef]

30. Shay, J.; Wagner, S.; Kasper, H. Efficient CuInSe 2 /CdS solar cells. Appl. Phys. Lett. 1975, 27, 89-90. [CrossRef]

31. Potter, R. Enhanced photocurrent $\mathrm{ZnO} / \mathrm{CdS} / \mathrm{CuInSe} 2$ solar cells. Sol. Cells 1986, 16, 521-527. [CrossRef]

32. Minemoto, T.; Julayhi, J. Buffer-less $\mathrm{Cu}(\mathrm{In}, \mathrm{Ga}) \mathrm{Se}_{2}$ solar cells by band offset control using novel transparent electrode. Curr. Appl. Phys. 2013, 13, 103-106. [CrossRef]

33. Okuda, K.; Chantana, J.; Fujita, Y.; Hironiwa, D.; Minemoto, T. Post annealing effect on buffer-free CuInS ${ }_{2}$ solar cells with transparent conducting $\mathrm{Zn}_{1-x} \mathrm{Mg}_{x} \mathrm{O}$ : Al films. Jpn. J. Appl. Phys. 2014, 53, 05FW04. [CrossRef]

34. Scheer, R.; Shock, H. Chalcogenide Photovoltaics Physics, Technologies, and Thin Film Devices; Wiley-VCH Verlag GmbH \& Co.: Weinheim, Germany, 2011.

35. Burgelman, M.; Nollet, P.; Degrave, S. Modelling polycrystalline semiconductor solar cells. Thin Solid Film 2000, 361, 527-532. [CrossRef]

36. Mostefaoui, M.; Mazari, H.; Khelifi, S.; Bouraiou, A.; Dabou, R. Simulation of high efficiency CIGS solar cells with SCAPS-1D software. Energy Procedia 2015, 74, 736-744. [CrossRef]

37. Egyna, D.; Abuzairi, T.; Poespawati, N.R. Band-gap optimization for improvement $\mathrm{Cu}(\mathrm{In}, \mathrm{Ga})(\mathrm{Se})_{2}$ solar cell. In Proceedings of the 2017 International Conference on Telecommunications and Communication Engineering, Osaka, Japan, 22-24 October 2017; pp. 70-74.

38. Toki, S.; Nishimura, T.; Sugiura, H.; Nakada, K.; Yamada, A. Improvement of $\mathrm{Cu}(\mathrm{In}, \mathrm{Ga}) \mathrm{Se}_{2}$ photovoltaic performance by adding $\mathrm{Cu}$-poor compounds $\mathrm{Cu}(\mathrm{In}, \mathrm{Ga})_{3}(\mathrm{Se})_{5}$ at $\mathrm{Cu}(\mathrm{In}, \mathrm{Ga})(\mathrm{Se})_{2} / \mathrm{CdS}$ interface. In Proceedings of the 2016 IEEE 43rd Photovoltaic Specialists Conference (PVSC), Portland, OR, USA, 5-10 June 2016; pp. 512-517.

39. Chelvanathan, P.; Hossain, M.I.; Amin, N. Performance analysis of copper-indium-gallium-diselenide (CIGS) solar cells with various buffer layers by SCAPS. Curr. Appl. Phys. 2010, 10, S387-S391. [CrossRef]

40. Würfel, U.; Cuevas, A.; Würfel, P. Charge carrier separation in solar cells. IEEE J. Photovolt. 2014, 5, 461-469. [CrossRef]

41. Brendel, R.; Peibst, R. Contact selectivity and efficiency in crystalline silicon photovoltaics. IEEE J. Photovolt. 2016, 6, 1413-1420. [CrossRef]

42. Roe, E.T.; Egelhofer, K.E.; Lonergan, M.C. Limits of contact selectivity/recombination on the open-circuit voltage of a photovoltaic. ACS Appl. Energy Mater. 2018, 1, 1037-1046. [CrossRef]

43. Rau, U.; Kirchartz, T. Charge carrier collection and contact selectivity in solar cells. Adv. Mater. Interfaces $2019,6,1900252$. [CrossRef]

44. Maeda, T.; Nakanishi, R.; Yanagita, M.; Wada, T. Control of electronic structure in $\mathrm{Cu}(\mathrm{In}, \mathrm{Ga})(\mathrm{S}, \mathrm{Se})_{2}$ for high-efficiency solar cells. Jpn. J. Appl. Phys. 2020, 59, SGGF12. [CrossRef] 